\title{
STRUKTUR ARGUMEN BAHASA MELAYU DIALEK AKIT PULAU PADANG KEPULAUAN MERANTI
}

\author{
Mohd. Fauzi ${ }^{1}$, Mulyadi ${ }^{2}$ \\ Universitas Lancang Kuning, Pekanbaru ${ }^{1}$ \\ Universitas Sumatera Utara, Medan² \\ mohd.fauzi_007@yahoo.co.id
}

\begin{abstract}
The writing attempted to describe the argument structure of Malay language Akit dialect in Padang Island, Kepulauan Meranti regency. Riau. The method used was descriptive-qualitative. The data was collected by using cakap method and simak method. The data analysis applies agih method with deletion technique, substitution technique. The data used was spoken language. The data was collected by using questionnaire, interviews, observation, and intuition methods. The source of data was Malay language Akit dialect. The result of the research showed that argument structures of Malay language Akit dialect are very simple. They have very limited vocabularies, phrases, clauses and sentences. They do not practice affixation in their speech.
\end{abstract}

Key words: Argument Structure, Dialect of Akit and Padang Island

\section{PENDAHULUAN}

Setiap masyarakat memiliki bahasa mereka sendiri yang tidak seluruhnya dipahami oleh masyakarat lainnya. Mereka memiliki struktur bahasa yang unik dan menjadi penanda identitas mereka sendiri. Dengan kata lain, keberagaman suku bangsa atau komunitas masyarakat yang memiliki struktur bahasa yang berbeda-beda akan menarik untuk dikaji sebagai salah satu tanggung jawab linguis dalam rangka menjelaskan fenomena bahasabahasa yang ada di masyarakat kita, dan juga mendokumentasikannya karena kemungkinan bahasa tersebut suatu saat akan pupus atau penuturnya sudah tidak ada lagi.

Perkembangan teknologi dan informasi telah memberikan dampak positif terhadap kehidupan manusia, tetapi juga menimbulkan dampak negatif terhadap kearifan lokal masyarakat di daerah-daerah 
terpencil. Salah satu dampak negatif yang sangat dirasakan adalah semakin tergerusnya bahasa-bahasa daerah. Bahasa Melayu dialek Akit yang ada di Kepulauan Meranti, Riau merupakan satu contoh bahasa daerah yang secara perlahan tergerus oleh perkembangan zaman. Sebelum masuknya televisi, handphone dan transportasi moderen serta berbagai suku bangsa di daerah ini, adat istiadat dan bahasa mereka terjaga dengan baik, tetapi saat ini sudah jauh berubah. Dalam berinteraksi, sering dijumpai mereka menggunakan bahasa Melayu dan banyak kosa kata yang dahulunya digunakan saat ini tidak ditemukan lagi. Jika dibiarkan terus, maka bahasa yang mereka miliki secara perlahan akan hilang.

Penelitian mengenai stuktur argumen bahasa Melayu dialek Akit di Pulau Padang Kepulauan Meranti, Riau perlu dilakukan dalam rangka mengangkat fenomena kebahasaan. Penelitian yang sudah pernah dilakukan terkait bahasa melayu Riau antara lain oleh Hasan dkk, (1983) dengan judul
"Morfologi dan Sintaksis Bahasa Melayu Riau" dan disertasi Tambusai (2016) “Tipologi Morfologis dan Struktur Argumen bahasa Melayu Riau”. Penelitian lainnya yang berkaitan dengan bahasa Melayu Riau adalah penelitian yang dilakukan Dahlan, dkk (1985), "Pemetaan Bahasa Melayu Riau dan Jambi”. Kajiankajian tersebut belum ada yang menjelaskan bahasa Melayu dialek Akit yang sesungguhnya memiliki beberapa perbedaan dalam struktur argumennya.

Penelitian-penelitian lain yang relevan dengan penelitian ini antara lain: (1) Wood (2012) dalam penelitiannya membahas "Icelandic Morphosyntax and Argument Structure"; (2) Jufrizal (2004) dalam penelitiannya "Struktur Argumen dan aliansi Gramatikal Bahasa Minangkabau"; (3) Taoka (2000) dalam penelitiannya "Aspect and Argumen Structure in Japanese".

Istilah argument dalam kajian tipologilinguistik, terutama pada tataran sintaksis merujuk ke unsure FN yang mendahului dan/atau 
mengikuti prediket klausa. Hal ini berarti bahwa argumen mirip pengertiannya dengan subjek dan/atau objek pada sebuah klausa. Dalam dasar-dasar teori tatabahasa dijelaskan bahwa (a) di antara unsurunsur yang membangun/membentuk kalimat ada bagian yang disebut prediket (predicate) dan (b) ada unsur lain dalam kalimat itu yang berperan sebagai argumen dari predikat tersebut (Jufrizal, 2012).

\section{Menurut Alsina (1996:4-7)}

sebuah predikat mengungkapkan hubungan antara pelibat-pelibat dalam sebuah klausa. Pelibat (partisipan) itulah yang disebut argumen predikat. Masing-masing predikat (verbal dan bukan verbal) mempunyai korespondensi (hubungan) logis dengan argumenargumennya. Hubungan fungsifungsi gramatikal (subjek), objek, oblik, dan sebagainya) dengan argumen predikat bukanlah bersifat acak atau tak terduga. Apakah argumen itu diungkapkan sebagai subjek, objek dan lainnya, sebagiannya ditentukan oleh semantik predikat. Setiap verba harus bersesuaian dengan argumennya. Keterikatan dan kaitan informasi yang menjadi argumen predikat dan predikat itu sendiri membentuk struktur, yang disebut strruktur argumen. Struktur argumen juga merupakan informasi minimal predikat yang perlu untuk menurunkan kerangka sintaksisnya.

Menurut Manning (1996:3536) dalam Azhari (2016:67), pengertian struktur argumen yang diberikan Alsina (1996) lebih dilihat sebagai perwujudan semantis daripada sintaksis. Manning sendiri menempatkan persoalan struktur argumen sebagai perwujudan sintaksis. Menurutnya, struktur gramatikal dan struktur argumen adalah hasil langsung dari gramatikalisasi dua rangkaian hubungan yang berbeda. Struktur gramatikal adalah hasil gramatikalisasi peran-peran wacana (discourse) sementara struktur argumen merupakan hasil gramatikalisasi pemikiran prominansi semantik.

Penelitian ini bertujuan untuk menganalisis dan menjelaskan 
struktur argumen bahasa Melayu dialek Akit di Pulau Padang di Kabupaten Kepulauan MerantiRiau. Dipilihnya bahasa Akit di daerah ini karena penulis ingin mendokumentasikan bahasa ini. Dalam membahas Bahasa Melayu dialek Akit selanjutnya disebut (BMDA), peneliti akan mengkaji struktur dasar klausa, tipologi tataurut kata klausa, struktur argumen dan sifat -perilaku gramatikal subjek, objek, dan oblik BMDA, sifat-perilaku agen dan pasien, serta struktur klausa majemuk setara dan klausa majemuk bertingkat BMDA.

Banyak pekerjaan yang sangat produktif dalam struktur argumen berfokus pada 'pergantian'; kasus di mana satu kata kerja tampaknya compatible dengan lebih dari satu struktur argumen. Satu baris pekerjaan, diwakili oleh Levin (1993), bertujuan untuk mengklasifikasikan kata kerja dasar yang secara semantik independen dalam rangka mencari tahu pergantian mana yang diikuti kelas semantik. Ternyata, bagaimanapun, klasifikasi semantik semacam ini hanya bisa sebagian memprediksi untuk perubahan struktur argumen. Untuk hampir setiap kelas kata kerja dalam Levin (1993), seseorang dapat menemukan kata kerja yang berbeda dari anggota kelas lainnya secara tidak mudah (Wood, 2012).

Pendapat yang serupa dengan Wood di atas, juga dipaparkan oleh Croft (2010) bahwa konstruksi struktur argumen, lebih kompleks dan kontroversial. Konstruksi tersebut menyimbolkan peran partisipasi dengan peristiwaperistiwa yang disimbolkan oleh prediket penanda kasus frasa argumen, indeksasi (kesepakatan dengan) frasa argumen yang digunakan untuk tujuan ini, urutan kata argumen, frasa dalam klausa deklaratif sederhana.

\section{METODOLOGI}

Jenis penelitian ini adalah deskriptif kualitatif. Penelitian deskriptif kualitatif merupakan penelitian yang bertujuan membuat deskripsi, membuat gambaran, lukisan secara sistematis, faktual 
dan akurat mengenai data, sifat-sifat serta hubungan fenomena-fenomena yang diteliti. Pemilihan jenis penelitian deskriptif di dalam penelitian bahasa, cenderung digunakan terutama dalam mengumpulkan data serta menggambarkan data secara ilmiah (Djajasudarma, 2006:9). Data adalah bahan jadi penelitian (Sudaryanto, 1990:66). Data penelitian ini adalah tuturan-tuturan bahasa Melayu dialek Akit di Pulau Padang. Pengumpulan data menggunakan teknik rekam dan teknik catat (Sudaryanto, 1992:33).

Penyajian hasil analisis data dalam penelitian ini dilakukan dengan menggunakan metode informal dan formal. Penyajian informal yaitu berupa rumusan dengan menggunakan kata-kata biasa, sedangkan penyajian formal adalah perumusan dengan tanda dan lambang-lambang (Sudaryanto, 1993:145). Demikian juga menurut Mahsun (2005:123) bahwa metode informal merupakan perumusan dengan menggunakan terminologi yang bersifat teknis, dan metode formal merupakan perumusan dengan menggunakan tanda-tanda atau lambang-lambang.

Alasan digunakannya metode informal dan formal dalam penyajian hasil analisis karena penelitian ini bersifat deskriptif. Maksudnya pendeskripsian dari gejala atau keadaan yang terjadi pada data penelitian. Penggunaan kedua metode tersebut karena selain penyajian dilakukan dengan menggunakan kata-kata biasa juga dengan menggunakan tanda dan lambang-lambang.

\section{HASIL}

DAN

\section{PEMBAHASAN}

\subsection{Struktur Dasar Klausa Suku Akit}

Klausa merupakan konstruksi sintaksis yang mengandung unsur predikasi. Klausa dasar memiliki ciri-ciri seperti (1) terdiri dari atas satu klausa (2) unsur intinya lengkap (3) susunan unsur-unsurnya menurut yang paling umum dan (4) tidak mengandung pertanyaan atau pengingkaran (Alwi, dkk: 2000). Agen dan pasien merupakan dua hal 
yang paling penting dalam kajian struktur argumen.

Bahasa suku Akit memiliki klausa dasar verbal dan klausa dasar bukan verbal. Klausa verbal adalah klausa yang prediketnya verba, sedangkan klausa bukan verbal adalah klausa yang prediketnya adalah nomina, pronominal, adjectiva maupun numeralia, misalnya;

(1) Aku titik dikaw 'Aku pukul dikau'

(2) Anak die lime? 'Anaknya tiga'

(3) Rumah- nye tepi laot 'Rumahnya di tepi laut'

(4) Die kepala suku 'Dia kepala suku'

(5) Mak aku di Toyok 'Mak ku di dapur'

Pada contoh (1) subjek klausa adalah $A k u$ dan prediketnya titik (verbal). Pada contoh (2) Anak die sebagai subjek dan kata lima (numeralia) sebagai prediket. Pada contoh (3) Rumahnye sebagai subjek (nominal) dan tepi laut (frasa preposisional) berfungsi sebagai prediket. Pada contoh (4) Die sebagai subjek (nominal) dan kepala suku (frasa nomina) berfungsi sebagai prediket. Pada contoh (5) Mak aku sebagai subjek (nomina) dan di Toyok (keterangan tempat)

Berikutnya, klausa verbal bahasa Melayu Riau ada yang morfem bebasnya sudah merupakan kata kerja tetapi ada juga yang disertai dengan afiksasi. Kehadiran afiksasi mejadi sebab morfem tersebut menjadi kata kerja, tetapi dalam pertuturan sehari-hari orang Akit, mereka tidak mengenali istilah afiksasi. Untuk mengekspresikan sesuatu, cukup bagi mereka dengan mengolah dan mengorganisasikan kosa-kata dasar yang ada. Bagi mereka prinsip dalam berkomunikasi adalah saling transfer pesan tidak lebih dari itu. Ketika pesan yang hendak disampaikan dapat ditangkap oleh lawan biccara maka pekerjaan penutur maupun lawan tutur dianggap selesai.

(6) Ibung jeRat babi Ibung menjerat babi'

(7) Budak tu noreh 'Anak itu sedang bekerja menyadap getah'

Struktur argumen klausa di atas sangat sederhana. Pada data 6 
leksikon jerat maksud sebenarnya adalah menjerat. Kategori nomina berubah menjadi verba. Demikian juga pada data 7 leksikon noreh maksud sebenarnya adalah menoreh. Ada tidaknya afiks pada verba tidak mempengaruhi struktur dasar klausa tersebut. Struktur dasar klausa tetap terdiri atas subjek, prediket, objek dan keterangan.

Selanjutnya pada data (5) Ibung dan data (6) Budak tu sebagai aktor yang melakukan tindakan. Ibung melakukan tindakan menjerat babi, sedangkan Budak tu melakukan tindakan menoreh 'mengambil getah dari pohon getah'. Aktor adalah argumen dari predikat yang menyatakan partisipan melakukan, mempengaruhi, menghasut, atau mengontrol situasi tindakan yang diperlihatkan melaluai verba (Foley dan Van Valin, 1984:29). Dengan demikian, dapatlah dikemukakan bahwa aktor memiliki peran penting yang dengan sengaja melakukan suatu tindakan. Aktor merupakan penyebab terjadinya suatu peristiwa.

\subsection{Klausa Transitif}

Klausa Transitif adalah klausa yang mengandung kata kerja transitif, yaitu kata kerja yang mempunyai kapasitas memiliki satu atau lebih objek. Hal tersebut sejalan dengan pendapat (Tarigan, 1986:38) bahwa klausa transitif adalah klausa yang mengandung kata kerja transitif, yaitu kata kerja yang mempunyai kapasitas satu objek atau lebih. Contohnya dalam dialek Akit;

(8) Samsi ambik kayu teki 'Samsi mengambil kayu teki'

(9) Mak aku buat kopi 'Mak saya membuat kopi'

(10) Die? Panjat pokok kayu $i k a$ ?

'dia memanjat pohon kayu itu

Contoh (7), (8) dan (9) yang dipaparkan mengandung kata kerja yang memerlukan objek. Kata kerja ambik, buat, panjat yang dinyatakan dalam data di atas merupakan kata kerja transitif diikuti kata-kata berikutnya yang melengkai makna kalimat. Jika objek dihilangkan, 
maksud kalimat menjadi tidak lengkap. Misalnya;

\section{(11) Samsi ambik 'Samsi mengambil' \\ (12) Mak aku buat 'Mak saya membuat' \\ (13) Die? Panjat 'dia memanjat'}

Contoh (10) hingga (12) merupakan kalimat yang tidak mempunyai unsur pelengkap ataupun objek setelah kata kerja transitif yang hadir dalam kalimat. Kalimat yang dihasilkan pun tidak gramatis karena struktur argumennya tidak lengkap. Dengan kata lain, kata kerja tersebut memerlukan unsur lain untuk melengkapi makna kalimat. Unsur yang diperlukan seperti yang dipaparkan dalam contoh (7) hingga (9) di atas.

Dalam prakteknya, suku Akit juga mengerti bahwa jika objek tidak dilekatkan maka maksud kalimat tidak sempurnya, dan komunikasi tidak mencapai hasil yang diharapkan. Prinsip komunikasi seperti ini terlihat di dalam percakapan sehari-hari kecuali untuk kalimat-kalimat tanya yang mengelipsikan beberapa kata sebelum atau sesudah kata inti karena dianggap pendengar sudah memahami maksud kalimat itu. Misalnya: pigi!, 'pergi' Tidek! 'tidak', Adoheh!'aduh!' Sika 'sini!'.

\section{SIMPULAN}

Struktur argumen bahasa Melayu dialek Akit memiliki keunikan tersendiri. Dalam bertutur, penutur tidak menggunakan ekspresi yang kompleks sebagaimana penutur dialek Melayu lainnya yang terdiri Subjek, Prediket, Objek dan Keterangan, tetapi mereka lebih sederhana dan tidak berbelit-belit. Jarang sekali mereka menggunakan afiksasi, tetapi mereka cenderung memanfaatkan peran aktor yang sering berpindah fungsi. Mereka hanya mengolah kata-kata yang mereka miliki sebagai kalimat. Mereka sendiri tidak ada upaya untuk mengembangkan bahasa mereka yang merupakan dialek Melayu Riau. Mereka lebih bersifat pasif, artinya tidak pernah memikirkan seperti apa nasib bahasa 
mereka ke depan. Eksistensi dialek Akit masih terjaga karena orangorang tua dan komunitas mereka masih mempergunakannya dalam keseharian mereka.

\section{DAFTAR PUSTAKA}

Alsina, A. 1996. The Role of Argument Structure in Grammar. Evidence from Romance. California: CSLI.

Chiaka Taoka. 2000. Aspect and Argumen Structure in Japanese. Disertasi. Tokyo: Department of Linguistics University of Manchester.

Croft, William. 1993. Typology and Universals. Cambridge: Cambridge University.

Dahlan, Saidat dkk. 1985. Pemetaan Bahasa daerah Riau dan Jambi. Jakarta: Pusat Pembinaan dan Pengembangan Bahasa Departemen Pendidikan dan Kebudayaan.

Djajasudarma. 2006. Metode Linguistik Ancangan Metode Penelitian dan Kajian. Bandung: PT. Eresco.

Foley, William A dan Robert D. Van Valin. 1984. Fungsional Syntax and Universal Grammar.Cambridge:

Cambridge University Press.
Hasan, dkk. 1983. Morfologi dan Sintaksis Bahasa Melayu Riau. Jakarta: Pusat Pembinaan dan Pengembangan Bahasa Departemen Pendidikan dan Kebudayaan.

Jufrizal. 2004. "Struktur Argumen dan Aliansi Gramatikal Bahasa Minangkabau" Disertasi". Denpasar Program Doktor (S3) Linguistik Universitas Udayana.

Jufrizal. 2012. Tatabahasa Minangkabau: Deskripsi dan Telaah Tipologi Linguistik. Padang: UNP Press.

Levin, Beth. 1993. English Verb Classes and Alternations. Chicago: The University of Chicago Press. Lockwood,W.B. 1955.

Mahsun. 2005. Metode Penelitian Bahasa: Tahapan Strategi, Metode, dan Tekniknya. Jakarta: Raja Grafindo Persada.

Manning, C.D. 1996. Ergativity: Argument Structure and Gramatical Relations. California: CSLI.

Sudaryanto. 1992. Metode dan Aneka Teknik Analisis Bahasa. Yogyakarta: Duta Wacana University Press.

Tambusai Azhary. 2016. “Tipologi Morfologis dan Struktur 
Jurnal Ilmu Budaya, Vol. 16, No. 2 Februari Tahun 2020

Argumen Bahasa Melayu

Riau". Disertasi. Medan USU.

Tarigan H.G. 1986. Prinsip-prinsip Dasar Sintaksis. Bandung: Angkasa.

Wood, Jim. 2012. Icelandic Morphosyntax and Argumen Structure. New York University: Department of Linguistics. 